\title{
EAl Endorsed Transactions

\section{From the Argentinian Bioart Laboratory to the Strange Things retrospective. Ten years of bioart in Argentina}

\author{
Natalia Matewecki ${ }^{1, *}$ \\ ${ }^{1}$ Instituto de Historia del Arte Argentino y Americano, Facultad de Artes, Universidad Nacional de La Plata, Argentina
}

\section{Abstract}

Bioart is an artistic genre that brings together works that use techniques, protocols, and methodologies from the fields of biology and, above all, biotechnology, for artistic ends. The first works of bioart in Argentina were created in 2008 following the creation of the Argentinian Bioart Laboratory. After a decade of intense creativity in the production of bioart in Argentina, this article presents an overview of the works that played a part in consolidating the genre in the country. The artworks discussed here were created in connection with the Argentinian Bioart Laboratory, and many also formed part of the retrospective exhibition Cosas Extrañas. Bioarte en la Argentina [Strange Things. Bioart in Argentina], which was held at the Center for Art at the National University of La Plata in 2019. The exhibition included eleven works from 20082018 by the following Argentinian artists: Daniel Álvarez Olmedo, Agustín Bucari, Gabriel Cicuttin, Joaquín Fargas, Luciana Paoletti, Darío Sacco, Guido Villar, Marina Zerbarini, and the collective Grupo Proyecto Untitled.

Keywords: bioart, contemporary art, Argentinian art.

Received on 13 February 2020, accepted on 24 February 2020, published on 27 February 2020

Copyright (C) 2020 Natalia Matewecki, licensed to EAI. This is an open access article distributed under the terms of the Creative Commons Attribution licence (http://creativecommons.org/licenses/by/3.0/), which permits unlimited use, distribution and reproduction in any medium so long as the original work is properly cited.

doi: 10.4108/eai.13-7-2018.163309

"Corresponding author. Email:nmatewecki@gmail.com

\section{The Creation of the Argentinian Bioart Laboratory}

In 2008, Joaquín Fargas founded the Argentinian Bioart Laboratory at Maimonides University in Buenos Aires, Argentina. This was the first laboratory in the country to focus on developing artworks that were connected to the biological sciences. The laboratory's board of directors was made up of artists, scientists, and academics from Maimónides University: the managing director was Alejandra Marinaro, the scientific director was Alfredo Vitullo, and the artistic director was Joaquín Fargas ${ }^{2}$.

2 The Argentinian Bioart Laboratory was in operation and its board of directors in place until June 2019, when the new university authorities decided to shut down this space for research and production. As a consequence, Joaquín Fargas decided to establish a new initiative in collaboration with
The laboratory was designed and implemented to enable artists to start using biotechnological practices. Its aims included developing artistic creations that contemplate the use of biotechnology; to explore the relationship between art, science, and technology; and to strengthen existing ties between local and international artists and scientists and encourage the forging of new ones.

The work that went on at the Argentinian Bioart Laboratory fell into four main categories: (a) biologicalthe work carried out in biotechnology laboratories

Alejandra Marinaro: the Latin American Bioart Laboratory, based at the Inter-American Open University. 
involving the use of scientific techniques and procedures to create, manipulate, or develop organisms under controlled conditions; b) technological - the development of robotic devices or technological objects that are connected with the study of or experimentation with the biological sciences; c) the visual record-the recording and documentation of the experiments undertaken in biotechnology laboratories, often using microscopes; and d) the critical and theoretical record - the study of artistic phenomena with the aim of creating reflective, historical, and theoretical thought processes.

The laboratory was officially opened when Incubaedro -an interactive installation by the interdisciplinary collective Proyecto Untitled in which Joaquín Fargas took part as a guest artist-was exhibited in the university hall. The work is a robotic structure in the form of an icosahedron that houses 45 in vitro orchids developed by the biologist Nora Mouso $^{3}$. In Alejandra Marinaro's words, Incubaedro represents "an interactive geometric reality within which a constructed version of nature operates, one that is analogous to the cognitive structures that scientists use to recognize the parameters of nature and make it subsist by artificial means" [1]. In other words, the piece suggests that it is possible to unite science, nature, and art.

Later that year, the artwork went on show as part of the Naturaleza intervenida [Interventions in Nature] exhibition at Recoleta Cultural Center in Buenos Aires (Fig. 1).

At the same exhibition, Joaquín Fargas presented the first version of Inmortalidad [Immortality], a culture of animal heart cells inside a bioreactor containing optical components that displayed the state of the cells. According to the artist, the piece seeks to fulfill the desire to transcend human existence by abolishing death and the aging process. Rooted in the human desire to project ourselves so far into the future that we overcome the finite nature of our existence, this artwork is an organic whole that is metaphorically transformed into a heart which seeks to go on beating indefinitely.

The final bioart exhibition of 2008 was Cultura $y$ Media [Culture and Media] at the General San Martín Cultural Center in Buenos Aires. Proyecto Untitled once again used orchids in the work they showed in this exhibition, this time as part of Invernadero lúdico [Playful Greenhouse], an interactive installation that symbolizes a 21 st-century ecosystem. The exhibition space where the work was placed was behind a large plate-glass window that allowed the public not just to see the installation but also to interact with sensors in the glass that triggered a series of signals.

\footnotetext{
3 The Oncidium bifolium, Epidendrum ibagüence orchids are found in the jungles of Argentina's Misiones province. At the Center for Biomedical, Biotechnological, Environmental, and Diagnostic Studies (CEBBAD) at Maimónides University, these plants are used for basic research. Through biotechnology, scientists express proteins that may turn out to be useful for developing veterinary vaccines.
}

These activated a fan, which imitated the movement of the wind; a water pump, which simulated rainfall; and a pulley system, which brought an in vitro orchid out of an acrylic hemisphere, alluding to the birth of a new kind of organism designed in the laboratory.

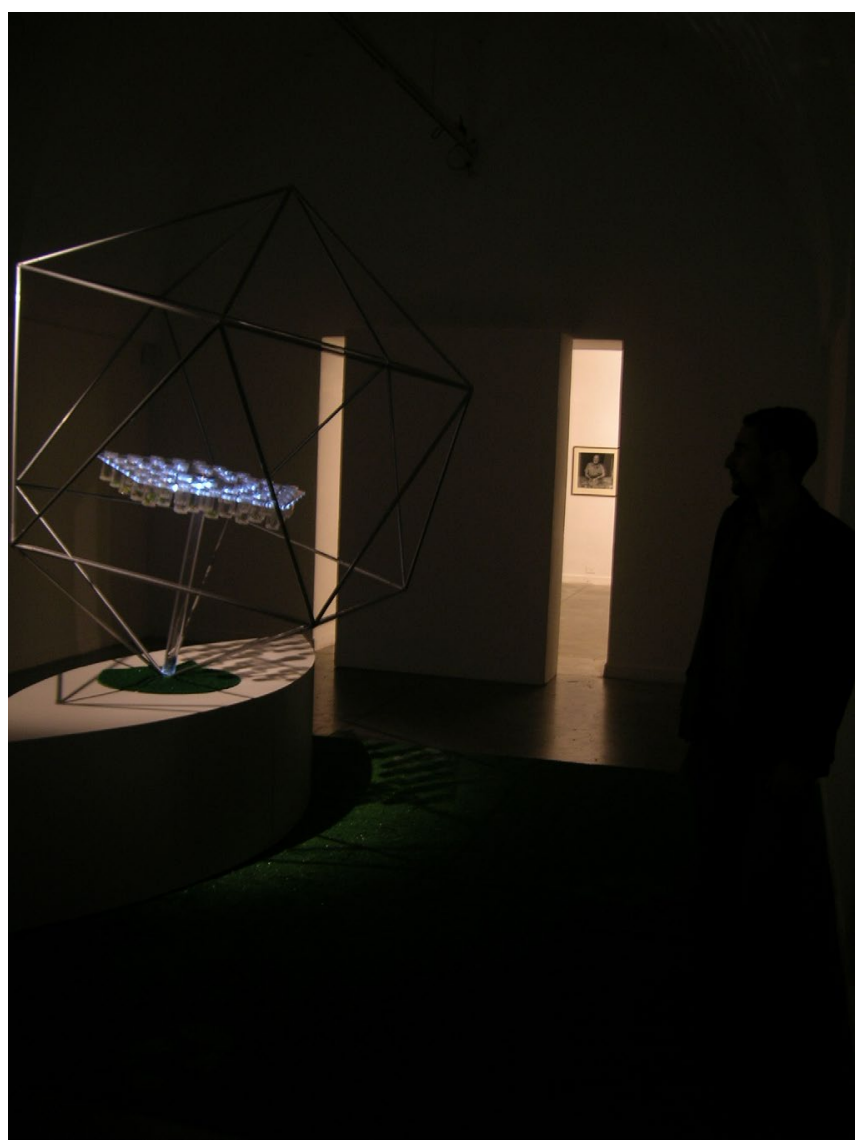

Figure 1. Grupo Proyecto Untitled and Joaquín Fargas, Incubaedro (2008). Photo Martín Alterisio

\section{The development and consolidation of bioart in Argentina}

After a prolific first year for the Argentinian Bioart Laboratory, the genre began to extend beyond the limits of the City of Buenos Aires as artists from other regions came onto the artistic scene. In 2009, biotechnologist and artist Luciana Paoletti began using bacteria and fungi to create bioart from her laboratory at the School of Biochemical and Pharmaceutical Sciences at the National University of Rosario, in Argentina's Santa Fe province. Paoletti collects microorganisms from different places and cultivates them using different microbiology protocols to make them visible under the microscope. Her underlying idea is to make that which cannot be seen with the naked eye visible. She used these techniques to create a series called Momentos [Moments], which is made up of digital photographs that show the microorganisms that were present in the air during the artist's birthday party. These photographs stand in for the snapshots we typically take at 
parties. For the Retratos [Portraits] series (Fig. 2), the person being portrayed did not need to pose: instead, their image came from microorganisms that were extracted from their body and which the artist then cultivated in a suitable media and photographed.

For the Paisajes [Landscapes] series, she photographed microorganisms that she collected from the banks of the Paraná River at sunset, on the night of carnival, or in Plaza San Martín in Rosario.

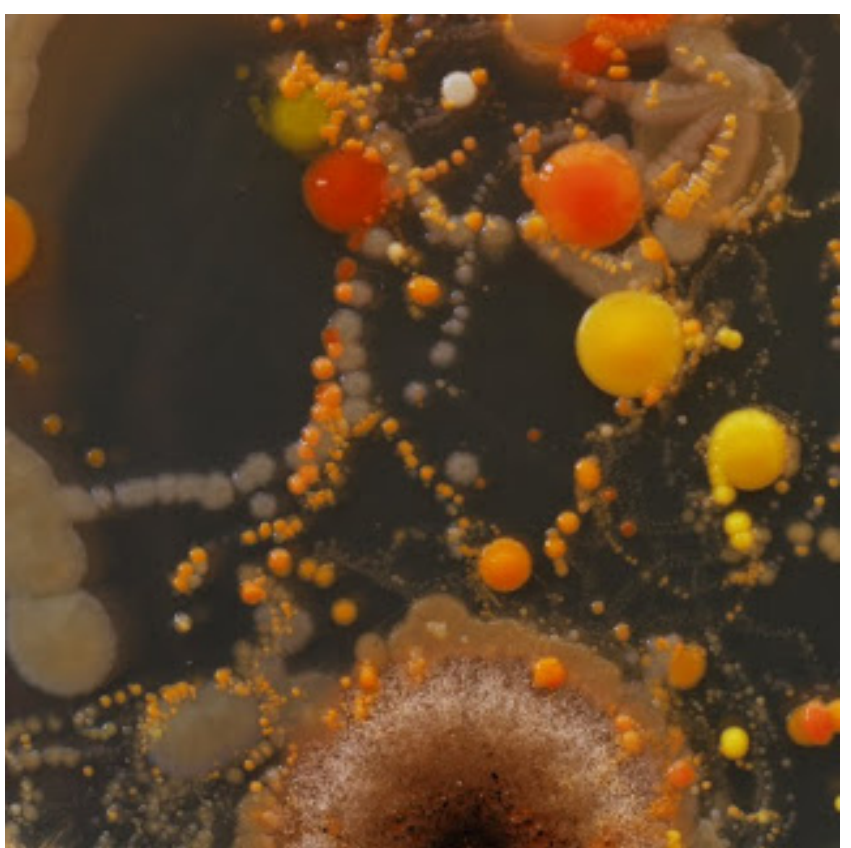

Figure 2. Luciana Paoletti, Portraits (2009). Photo courtesy of the author

Meanwhile, in the City of Buenos Aires, Proyecto Untitled produced two works of bioart that would be exhibited in 2010: Edenia and Late [It Beats]. Edenia was an interactive installation that represented a futuristic garden. The work was displayed in a dark room full of cables that were twisted around on the floor and rose up like roots forming tree trunks. On each of these technotrunks there was a plant that was illuminated by an external light source that was reminiscent of an artificial sun. The plants populating the installation were hybrids that contained both organic and inorganic parts: organisms that were part-biological and parttechnological. The plants included orchids from the scientific laboratories at Maimónides University displayed alongside Floris lupus, a mechanical flower that interacts with the public by opening and closing its petals depending on how close they come to it.

Late is an interactive installation made up of nine glass cubes filled with water onto which the growth and development of an embryo up to the fetal stage was projected. The images show about nine weeks of life, from the point at which the egg is artificially fertilized through the process of gestation, using footage of embryos and 3D animations of prenatal ultrasounds ${ }^{4}$. Complementing the images are sounds taken from ultrasound scans for each of the gestational periods shown in the videos. The process unfolds normally provided there are no spectators nearby: the embryo evolves and grows inside the cubes of water that provide it with the perfect protection (a clear allusion to the mother's womb), and the sounds gradually change as the process of embryogenesis develops. However, when a viewer gets too close to the artwork, motion sensors are triggered, setting off alarms to deter them from coming too close. The visitor's presence throws the process into reverse: the embryos stop developing and instead shrink until they return to the moment of fertilization.

Another artistic collective that emerged in Buenos Aires is@Agua_y_Aceite, made up of Daniel Álvarez Olmedo and Guido Villar. In 2011, the pair received guidance from the biologists, biochemists, and the support from the Argentinian Bioart Laboratory, to create Generación de conciencia I y II [Generation of Consciousness I and II], which sought to draw attention to the current state of Argentina's public health system by displaying statistical data.

Generation of Consciousness I was a robotic installation that centered on a hospital IV stand in which the saline solution had been replaced by a red liquid containing human hair, fat, and nail clippings (Fig. 3). The liquid symbolized the blood of all those who had died in Argentina between 1980 and 2007. The drip was connected to an on-off valve that limited the passage of the liquid into a receptacle filled with water containing live bacteria. These microorganisms clustered around each drop of the liquid as it entered the water, seeking to devour its organic content. The process was transmitted through a microscope that captured the images and projected them onto a screen.

Each drop of liquid represented a thousand deaths, based on the mortality rates for 1980, 1990, 2000, 2004, 2005, 2006, and 2007, as recorded by Argentina's National Department of Health Statistics and Information. The installation is autonomous up to a point, as it makes its calculations based on information from the statistics, such that more liquid is released for years when the mortality rate was highest. Through the work, the artists are attempting to send a poetic message regarding the collapse of the public hospital system, in that each drop of liquid represents the thousands of people who die because they do not have good medical care and who are effectively devoured by a system that profits from people's ill-health [2].

\footnotetext{
${ }^{4}$ The work was made possible through the collaboration of the Center for the Study of Gynecology and Reproduction (CEGyR) and the Center for Biomedical, Biotechnological, Environmental, and Diagnostic Studies (CEBBAD) at Maimónides University.
} 
Generation of Consciousness II was a continuation of this first work and drew on the same statistical data. This interactive video installation was made up of a white cylinder that housed a transparent acrylic container (rather like an oversized Petri dish). Inside this was the organic waste left by the microorganisms that fed on the dripping liquid from Generation of Consciousness I. Videos of microorganisms that were filmed earlier in the laboratory and a series of statistical data that was activated by the viewers were projected onto the acrylic container.

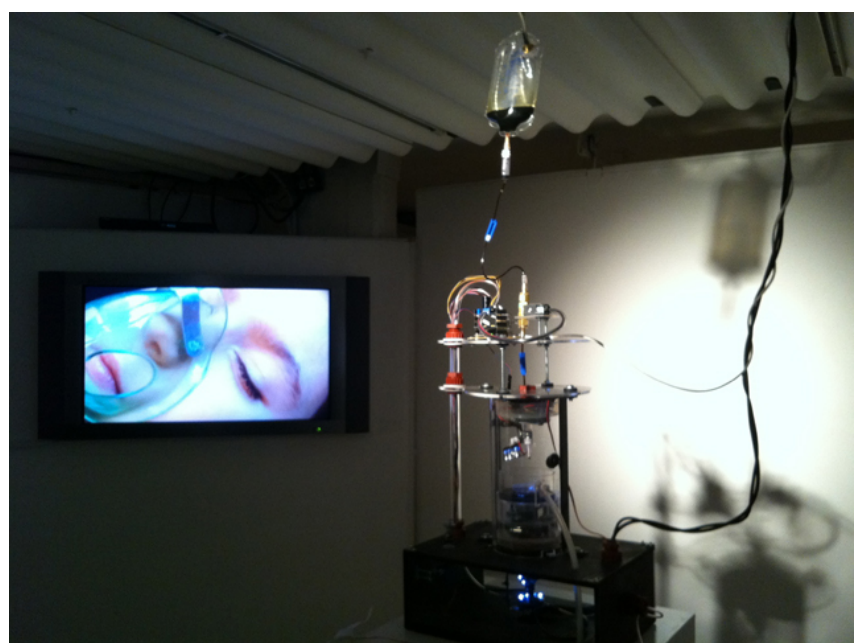

Figure 3. Daniel Álvarez Olmedo and Guido Villar, Generation of Consciousness I (2011). Photo courtesy of the authors

Whenever a member of the public went near the installation, their presence was captured by a sensor on the top of it. As the viewer moved toward the white cylinder, they walked over a projection on the floor showing three concentric circles containing information that was constantly rotating. The outer circle is the Year Zone and shows the years between 1980 and 2007 when national mortality rate statistics were gathered. The middle circle is the Age Zone, and the inner circle is the Gender Zone, which is divided into male and female populations. When the viewer stops in any of these areas, the circles stop turning and the number of deaths per thousand for the three parameters in question (year, age range, and gender) is projected onto the acrylic container.

The information used in the two works are from the same official database: in Generation of Consciousness I, it is visualized in a more poetic, metaphorical way through the dripping of colored liquid, while in Generation of Consciousness II, the information is presented more literally and directly, by displaying numbers that show the state of health in Argentina.

The artists and creative spaces that focused on bioart began to gain momentum, and in 2012 Luciana Paoletti continued her experiments with fungi and bacteria, this time to create the series Pinturas [Paintings]. After researching and producing colors using microbiology techniques, Paoletti made sketches on paper that then took shape and developed color on cultured Petri dishes plates.
When the image she could see under the microscope was the same as the sketch, she photographed this and exhibited printed copies of the photos.

The same year, Joaquín Fargas created a performance piece for BioWear, which revolves around the possibility of wearing a fabric made of epithelial cells as though it were a second skin. The live-action part of the work took place in the hall of the San Martín Theater in Buenos Aires, where the artist had epithelial tissue removed from his arm with a scalpel. The cells were placed in a sterile container and transported immediately to the Argentinian Bioart Laboratory to be cultured so as to create a second skin that was somewhere between the natural and the artificial.

The strengthening of the connections between these artists and scientific institutions was evident in the work of the Proyecto Untitled group, who collaborated with different teams of scientists at Maimonides University and other universities and medical centers to create two pieces: a priori and Umbilical, which were shown at biennials and exhibitions on art, science, and technology. The first of these was created for the 2nd Kosice Biennial ${ }^{5}$, the theme for which as "hydrospatial cities". Proyecto Untitled reflected on who or what would inhabit such a city and came up with a resistant, primordial inhabitant with an enduring presence that was reminiscent of early life on Earth. Their idea was to create a city of test tubes, petri dishes, burettes, flasks, balloons, cooling tubes, and Büchner funnels that would house harmless bacteria in nutrients that would change color as the bacterial population grew and reproduced.

a priori is an installation that seeks to reinterpret how the life cycle functions and to study the evolutionary patterns of bacteria and how they survive in order to extrapolate these patterns to the life cycle of society so as to understand our present and future as a community. To create the piece, the group contacted bacteriologists from the National University of Quilmes who suggested a series of bacteria and different colored substrates. Proyecto Untitled selected the organisms and substrates they thought were most suitable for the project, and the team of bacteriologists was responsible for growing them and establishing them inside the capsules that made up the installation. The piece included a population counter that tracked the growth of the bacteria according to changes in the conditions of each culture.

Umbilical once again demonstrated the artists' interest in life and its origins. It is a large-scale interactive installation made up of acrylic walls, rather like cell walls, onto which microfilms of organic fluids are projected. The walls contain motion sensors that set off sound effects and change the visuals of the projection when people approach the work. Behind the walls is a column

\footnotetext{
5 The name of the biennial is in honor of Gyula Kosice, a Czechoslovakian-born artist based in Argentina since 1928. He was a pioneer in incorporating light, water and neon gas to create hydrokinetic sculptures.
} 
containing human umbilical cords preserved in formaldehyde.

In 2013, Proyecto Untitled and Joaquín Fargas traveled to the city of Linz, Austria, to take part in the well-known Ars Electronica festival. Fargas presented a piece he had conceived of eight years earlier, called the Big Brain Project, which was a culture of neuronal cells that were connected through the internet. This was made possible by the molecular biologist Jorge Genovese, who decided that the neuronal cells in the original design would be replaced by a cell line known as PC12 (rat adrenal medulla cells), which are easy to handle and can be obtained in many parts of the world. Big Brain Project had two hubs, one in Austria and one in Argentina. Cultures and sensors were set up in both locations and were activated to produce different kinds of waves. The installation included voice, touch, temperature, and electromagnetic wave sensors. Each wave interacted with the others to create a unique local wave pattern. These local waves were stored on a server and were then combined to create a single wave that symbolized the great universal brain.

Another project that was years in the making was Marina Zerbarini's Síntesis simbiótica entre un ser vivo y una máquina [Symbiotic Synthesis between a Living Being and a Machine]. The idea for the work arose during the Interactivos workshop, an art program promoted by Espacio Fundación Telefónica in Argentina. Zerbarini was inspired by the history of the incubator as an artifact that connects the natural and the technological. After three attempts between 2010 and 2013, she successfully hatched seven chicks in an artificial incubator of her own design.

Exploring the behavior of complex living organisms such as animals appealed not just to Marina Zerbarini but also to Darío Sacco, who worked on the behavior of a group of fish in a sound-based artwork produced between 2005 and 2006. Ten years later, in 2015, Sacco joined forces with the veterinarian Gabriel Cicuttin to analyze the behavior of microorganisms as part of the research project "Evolución/Involución. Hacia una teoría de las obras de arte que siguen sus propios designios vitales" [Evolution/Involution. Toward a Theory of Artworks that Follow Their Own Intentions], which was based at the National University of Tres de Febrero. The project entailed conducting various experiments with microorganisms to be used to produce artworks. To this end, they began to experiment with cultivating microorganisms from their immediate surroundings in Petri dishes, the aim being to analyze the amount of energy (voltage) these produced and then to use this to create sound works. This research and experimental work continued with the production of microbial fuel cells $(\mathrm{MFCs})^{6}$ that store living microorganisms. For several

\footnotetext{
${ }^{6}$ Microbial fuel cells (MFCs) are devices that produce electrical current through the decomposition of a certain type of substrate via the action of bacteria that produce a flow of electrons when
}

months, they measured the voltages produced by the different cultures once or twice a week. The best results came from household compost (organic waste mixed with soil). This was the substrate they used to create the MFCs for Colonia [Colony], Colonia (lab) [Colony (lab)], and Oscilaciones Bacterianas [Bacterial Oscillations].

Colony was a sound installation that was exhibited at the Muntref [Museum of the National University of Tres de Febrero] in 2015 and was made up of hybrid beings created out of obsolete technology and biounits of decomposing organic material. These beings produced energy that regulated the oscillation frequency of a wave that is emitted through a speaker connected to a small amplifier (Fig. 4). As a whole, the entire colony functioned as a single body of sound that varied depending on the voltage produced by the microorganisms in each of these bio-technological beings.

The following year, in 2016, Sacco created Colony (lab), an installation that recreated the process of working with living organisms, art, and technology. The work is a sort of mapping of each point in the research and development of the academic project: sketches, notes, books, laboratory material, bacteria cultures, obsolete technology, videos, and the bio-technological beings used in Colony.

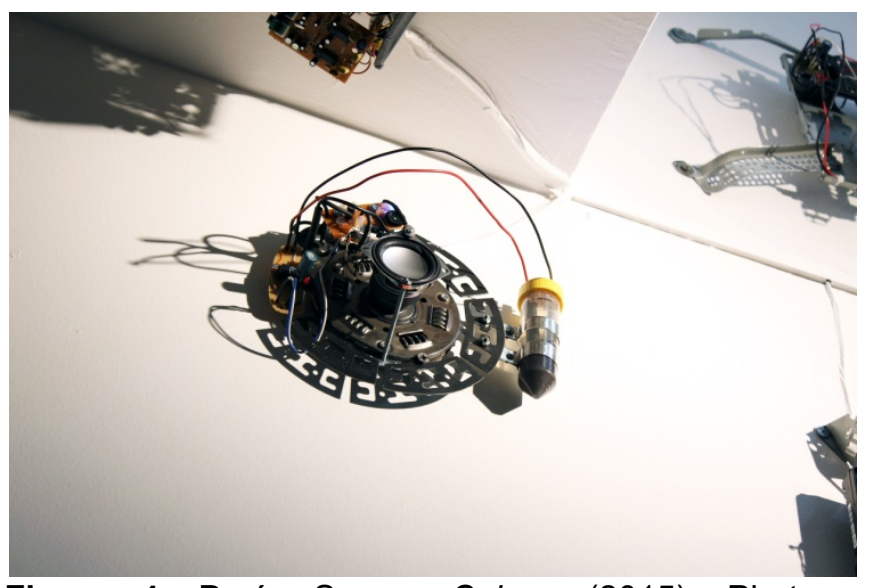

Figure 4. Darío Sacco, Colony (2015). Photo courtesy of the author

In Bacterial Oscillations, first performed in 2016, Sacco created a live show in which he and Gabriel Cicuttin performed using an array of MFCs by producing and mixing sounds in real time. During the performance, the microorganisms controlled the frequency of the oscillators, thus generating different sound patterns. Gabriel mixed these patterns from a computer and Darío added to the live composition by playing the keyboard.

they perform standard metabolic processes such as growing and reproducing. In this case, the MFCs are made up of two electrodes (aluminum/carbon) that form the negative and positive poles, which carry out the process and ordering the flow of electrons when they begin a chemical reaction inside the test tube. 
In 2018, Agustín Bucari, an artist from La Plata, showed two works at an exhibition of the Juan Batlle Planas collection at the Center for Art at the National University of La Plata: a video and an installation that show his research and experiments with his "cabbage crystals".

The installation, Morfogénesis S/Z [Morphogenesis S/Z] (2018) shows the different states of two materials: red cabbage (Brassica oleracea) and Potassium alum (Fig. 5). These materials were chosen based on the concepts of what the organic and the inorganic, not as a binary opposition, but rather as malleable, converging qualities that relate to one another. For example, when creating alum crystals, terms like "cultivation," "germination," or "growth" are used, which evoke organic characteristics. However, when Bucari observed cabbage leaves under the microscope, he found a structure of rigid, straight lines, a geometric pattern that repeats itself and relates to the inorganic forms of the design. The artwork is thus not only about the ambiguity between the organic and the inorganic but also the crossover between art and science.

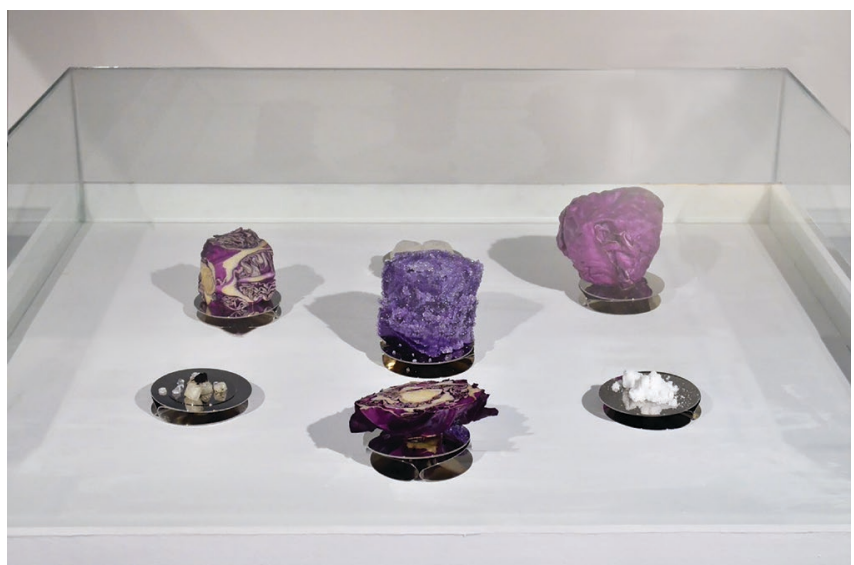

Figure 5. Agustín Bucari, Morphogenesis S/Z (2018). Photo Pilar Marchiano

\section{A retrospective exhibition}

In 2019, the first-ever full-scale exhibition of bioart was held in Argentina. The exhibition, Strange Things. Bioart in Argentina was curated by Natalia Matewecki, from Argentina, and Daniel López del Rincón, from Spain. The exhibition was held between April and May at the Center for Art at the National University of La Plata. The eleven artworks on display paid testimony to how important bioart has become in Argentina since the Argentinian Bioart Laboratory was opened.

The artists included in the exhibition give a sense of where and when bioart has been produced in Argentina over the last decade. The exhibition included the following works:

1. Grupo Proyecto Untitled, In Vitro Orchid Installation (used in several works), 2008-2010. Installation.
2. Joaquín Fargas, Project Biosphere, 2008. Installation.

3. Marina Zerbarini, Symbiotic Synthesis between a Living Being and a Machine, 2010-2013. Video

4. Luciana Paoletti, Captures, 2011. Digital photography

5. Daniel Álvarez Olmedo and Guido Villar, Generation of Consciousness, 2011. Video

6. Grupo Proyecto Untitled, Umbilical, 2012. Interactive installation.

7. Joaquín Fargas, Big Brain Project, 2013. Interactive installation.

8. Darío Sacco, Colony, 2015. Installation.

9. Darío Sacco and Gabriel Cicuttin, Bacterial Oscillations, 2016. Performance.

10. Agustín Bucari, Morphogenesis S/Z, 2018. Video installation.

11. Luciana Paoletti, My Plants (Dynamic Representations), 2018. Installation.

As the exhibition catalog explains, "seen together, these works explore different ways of approaching nature, matter, and life through a methodological shift that positions the artists' strategies in an interstitial space that draws on experiences from both the technical-scientific and the artistic-humanistic spheres" [3]. For this reason, the exhibition included a series of activities that revealed the connections, intersections, and points of contact between art and science. Experts from the worlds of both art and science led the activities such as:

- A talk and workshop entitled The Wonderful World of Crystals, organized by the Argentinian Crystallography Association. The talk explained the different ways that crystals are grown and how they are used in the fields of art and science. The workshop involved high-speed crystal-growing experiments.

- Art and Science: A Strange Relationship, a panel discussion among Flavia Costa, Constanza Pedersoli, and Javier Samaniego García, who reflected on the current linkages between art and science from their own perspectives.

- A workshop for children on microscopes and scientific illustration led by Agustín Bucari in conjunction with the School of Exact Sciences at the National University of La Plata. At the workshop, samples were taken of the organic matter included in some of the works on display, and these were then examined under the microscope. As well as observing the samples, the children made drawings of them like scientific illustrators do.

Strange Things. Bioart in Argentina encouraged the creation of bioart and reflection and debate around forms of joint work between disciplines that tend to be thought of as separate or even conflicting spheres. In this sense, the exhibition functioned as a platform that consolidated the genre of bioart in Argentina and opened up ways of understanding the world in a more integrated fashion. 


\section{Conclusions}

Bioart is an artistic practice that has emerged in Argentina over the last ten years and includes various other projects and artists that have not been discussed in this paper but will be the topic of future studies (like Marcello Mercado, Laura Olalde, and Ana Laura Cantera, among other artists).

This article has provided an overview of Argentinian bioart taking the creation of the Argentinian Bioart Laboratory and the projects that emerged from it as a starting point, while also discussing works by artists that were involved in the retrospective exhibition Strange Things. Bioart in Argentina, which was held at the Center for Art at the National University of La Plata in 2019.

All of the artists mentioned above have ties with academic institutions in Argentina. Fargas and the Proyecto Untitled group work at Maimónides University; Paoletti at the National University of Rosario; Álvarez Olmedo, Villar, and Sacco at the National University of Tres de Febrero; Zerbarini at the National University of the Arts; and Bucari at the National University of La Plata. Their ties to these academic institutions allow these artists to interact with specialists from other schools or departments and to create works that are part of official research and development projects. As this article has shown, the pieces in question entailed interdisciplinary work between artists, scientists, and technicians whenever the institutional context enabled relationships of this type to emerge.

As a consequence, we would like to emphasize the importance of dialogue and respect for the work of each party involved in the production of these interdisciplinary creations, since the connections, relationships, and collaboration described in this paper are what have made Argentinian bioart a reality.

\section{References}

[1] Marinaro, A. [dir.] (2013). Proyecto Untitled. Arte, ciencia y tecnología (Buenos Aires City: Universidad Maimónides).

[2] Álvarez Olmedo, D. (27 Dec 2012). Antecedentes artísticos - Arte, Ciencia y Tecnología. Available at: https://proyectoaguayaceite.wordpress.com/2012/12/27/ant ecedentes-artisticos-arte-ciencia-y-tecnologia

[3] MateweCKi, N. and LóPez del Rincón, D. (2019). Strange Things. Bioart in Argentina (La Plata: Centro de Arte UNLP). Available

https://www.centrodearte.unlp.edu.ar/wpcontent/uploads/2019/04/Cosas-Extra\%C3\%B1 as.pdf 